OPEN ACCESS

Edited by:

Samir G. Sakka,

Witten/Herdecke University, Germany

Reviewed by:

Vsevolod V. Kuzkov,

Northern State Medical University,

Russia

Angélique M. E. Spoelstra-de Man, VU University Medical Center,

Netherlands

*Correspondence:

David L. Stahl

david.stah@@sumc.edu

Specialty section:

This article was submitted to Intensive Care Medicine and

Anesthesiology,

a section of the journal

Frontiers in Medicine

Received: 18 December 2015

Accepted: 17 May 2016

Published: 30 May 2016

Citation:

Kimura S, Stoicea N, Rosero Britton BR, Shabsigh M, Branstiter A and Stahl DL (2016)

Preventing Ventilator-Associated

Lung Injury: A Perioperative

Perspective.

Front. Med. 3:25

doi: 10.3389/fmed.2016.00025

\section{Preventing Ventilator-Associated Lung Injury: A Perioperative Perspective}

\author{
Satoshi Kimura, Nicoleta Stoicea, Byron Rafael Rosero Britton, Muhammad Shabsigh, \\ Aly Branstiter and David L. Stahl*
}

Department of Anesthesiology, The Ohio State University Wexner Medical Center, Columbus, OH, USA

Introduction: Research into the prevention of ventilator-associated lung injury (VALI) in patients with acute respiratory distress syndrome (ARDS) in the intensive care unit (ICU) has resulted in the development of a number of lung protective strategies, which have become commonplace in the treatment of critically ill patients. An increasing number of studies have applied lung protective ventilation in the operating room to otherwise healthy individuals. We review the history of lung protective strategies in patients with acute respiratory failure and explore their use in patients undergoing mechanical ventilation during general anesthesia. We aim to provide context for a discussion of the benefits and drawbacks of lung protective ventilation, as well as to inform future areas of research.

Methods: We completed a database search and reviewed articles investigating lung protective ventilation in both the ICU and in patients receiving general anesthesia through May 2015.

Results: Lung protective ventilation was associated with improved outcomes in patients with acute respiratory failure in the ICU. Clinical evidence is less clear regarding lung protective ventilation for patients undergoing surgery.

Conclusion: Lung protective ventilation strategies, including low tidal volume ventilation and moderate positive end-expiratory pressure, are well established therapies to minimize lung injury in critically ill patients with and without lung disease, and may provide benefit to patients undergoing general anesthesia.

Keywords: lung protective ventilation, low tidal volume ventilation, ventilator-induced lung injury, ventilatorassociated lung injury, acute respiratory distress syndrome, general anesthesia

\section{INTRODUCTION}

Atelectasis is a common adverse effect of general anesthesia associated with both hypoxemia and postoperative respiratory complications (1-3). Mechanical ventilation (MV) may be used to combat atelectasis by prescribing relatively large tidal volumes $\left(\mathrm{V}_{\mathrm{T}}\right.$ ) [up to $15 \mathrm{~mL} / \mathrm{kg}$ predicted body weight $(\mathrm{PBW})](4,5)$. However, we now know that using high $\mathrm{V}_{\mathrm{T}}$ ventilation in the intensive care unit (ICU) increases mortality (6), and that MV itself can cause lung injury, through a process referred to as ventilator-induced lung injury (VILI) (7). VILI occurs through a number of different mechanisms. 
Barotrauma, defined as pulmonary injury from elevated transpulmonary pressures, was the first widely recognized element of VILI $(7,8)$. Since it was subsequently demonstrated that humans could generate high airway pressures without causing lung injury, clinical focus shifted to volutrauma, hyperaeration caused by high $\mathrm{V}_{\mathrm{T}}$ leading to lung injury $(7,8)$. Conversely, atelectrauma occurs when tidal ventilation at low airway pressures causes cyclic opening and collapse of unstable lung units $(7,9)$. This repeated cycling generates disruptive forces on the alveolar basement membranes and augments lung injury (7). Since the early 1990s, numerous studies have shown that MV can trigger the release of pro-inflammatory cytokines and the recruitment of neutrophils (10-13). This biological reaction in response to mechanical forces is known as biotrauma $(8,9,14,15)$.

Clinically, it can be difficult to delineate MV as the precise cause of lung injury. Therefore, when lung injury is concurrent to, but not necessarily caused by, MV, the term ventilator-associated lung injury (VALI) is used (7). The potentially detrimental effects of MV were recognized as early as 1960s (16) when canine studies demonstrated that lung overdistension resulted in an absence of surfactant and subsequent atelectasis (17). Attempts to prevent lung overdistention by therapeutically reducing $\mathrm{V}_{\mathrm{T}}$ in humans in the ICU became feasible with acceptance of permissive hypercapnia (18).

Over the past 15 years, studies of patients with acute respiratory failure have resulted in the development of a number of lung protective strategies applied to minimize VALI. These strategies include low $\mathrm{V}_{\mathrm{T}}$ to limit volutrauma, higher positive end-expiratory pressure (PEEP) to prevent atelectrauma, and recruitment maneuvers (i.e., application of temporary high airway pressures to reinflate collapsed lung units) (19). The successful application of these strategies in acute respiratory failure has led to increased interest in applying these principles to other patient populations. What remains controversial is whether the principles of lung protective ventilation derived from ICU patients with acute respiratory failure have applicability to otherwise healthy patients in the operating room.

\section{MATERIALS AND METHODS}

A systematic literature search was performed to identify clinical studies of lung protective ventilation strategies. We searched PubMed, EMBASE, and the Cochrane Library from inception to May 2015 with restriction to human studies published in English using a combination of standardized search terms and keywords to cover the topics of acute lung injury, acute respiratory distress syndrome (ARDS), MV, lung protective ventilation, low $\mathrm{V}_{\mathrm{T}}$ ventilation, and general anesthesia. We reviewed articles that investigated the effects of lung protective ventilation strategies. We included randomized controlled trials (RCT), cohort, crosssectional, and before-and-after studies. References of all studies were inspected for additional articles that were not identified by the electronic database search. We removed non-human studies, case reports, abstracts, and any other study where the full text was unavailable. Additionally, we excluded studies that specifically examined one-lung ventilation.

\section{RESULTS}

\section{Origin of Lung Protective Strategies: Patients with ARDS and Acute Respiratory Failure in the ICU}

In 1998, Amato et al. described a lung protective strategy, which included a $V_{T}$ of $<6 \mathrm{~mL} / \mathrm{kg}$, PEEP above the lower inflection point, and permissive hypercapnia, was associated with improved survival at 28 days, an improved rate of weaning from $\mathrm{MV}$, and a lower rate of barotrauma in patients with ARDS (20). In 2000, The Acute Respiratory Distress Syndrome Network reported that lower $\mathrm{V}_{\mathrm{T}}(6 \mathrm{~mL} / \mathrm{kg}$ of PBW $)$ resulted in decreased mortality and increased ventilator-free days compared with $\mathrm{V}_{\mathrm{T}}$ of $12 \mathrm{~mL} / \mathrm{kg}$ of PBW (6). An increase of $1 \mathrm{~mL} / \mathrm{kg}$ PBW in initial $\mathrm{V}_{\mathrm{T}}$ has been associated with a $23 \%$ increase in ICU mortality risk (21). In patients without ARDS, a retrospective cohort study demonstrated the use of large $V_{T}$ was the main risk factor associated with the development of lung injury (odds ratio 1.3 for each milliliter/kilogram above $6 \mathrm{~mL} / \mathrm{kg}$ PBW, $p<0.001$ ) (22). And a prospective study conducted by the same group concluded that initial ventilator settings of high $\mathrm{V}_{\mathrm{T}}$ (odds ratio 2.6 for $\mathrm{V}_{\mathrm{T}}>700 \mathrm{~mL}$ ) and high peak airway pressure (odds ratio 1.6 for peak airway pressure $>30 \mathrm{cmH}_{2} \mathrm{O}$ ) were associated with the development of ARDS in patients without ARDS at the onset of MV (23).

\section{Lung Protective Ventilation during General Anesthesia in Operating Room}

Although lung protective ventilation strategies are widely used in the ICU, it remains unclear if these strategies can be directly translated into use in the operating room. Respiratory complications are low in patients undergoing general anesthesia, unlike the ICU (24). Therefore, it may take a much larger number of patients to improve outcomes using lung protective strategies, and there are risks associated with lung protective ventilation, including increased alveolar collapse (25), increased right ventricular afterload (26), hypercapnia and respiratory acidosis (27), and worsened metabolic acidosis (27). Studies on intraoperative MV can be divided into those that target surrogate markers of lung inflammation/injury, clinical outcomes, or systemic reviews and meta-analyses. We examine these studies to better understand the risks and benefits of lung protective ventilation in the operating room (Table 1).

\section{Lung Protective Ventilation, Pulmonary Biomarkers, and Lung Mechanics}

Inflammatory biomarkers can be used as surrogate outcomes for lung inflammation or injury in patients receiving MV. For example, one RCT compared 40 patients undergoing elective coronary artery bypass grafting $(\mathrm{CABG})$ receiving high $\mathrm{V}_{\mathrm{T}}$ /low PEEP or low $\mathrm{V}_{\mathrm{T}}$ /high PEEP (28). After $6 \mathrm{~h}$ of MV, interleukin (IL)-6 and IL-8 levels were elevated in bronchoalveolar lavage (BAL) fluid and plasma in patients who received higher $\mathrm{V}_{\mathrm{T}} /$ low PEEP, suggesting alveolar lung inflammation (28). The attenuation of IL-8, but not IL- 6 levels by lung protective ventilation has been replicated in other surgical patients undergoing cardiopulmonary bypass (29) as well as elective surgery (30) but not in major abdominal, thoracic (31), or spinal surgery (32). IL-10 has 
TABLE 1 | Randomized controlled trials comparing lung protective strategies with low tidal volumes to conservative ventilation in operating room.

\begin{tabular}{|c|c|c|c|c|c|}
\hline $\begin{array}{l}\text { Type of } \\
\text { surgery }\end{array}$ & Source & Patients' population & $\begin{array}{l}\text { Lung protective } \\
\text { ventilation }\left(\mathrm{V}_{\mathrm{T}}\right)\end{array}$ & $\begin{array}{l}\text { Conservative } \\
\text { ventilation }\left(V_{\mathrm{T}}\right)\end{array}$ & Primary outcome \\
\hline \multirow[t]{5}{*}{$\begin{array}{l}\text { Cardiac } \\
\text { surgery }\end{array}$} & $\begin{array}{l}\text { Chaney et al. } \\
(36)\end{array}$ & $\begin{array}{l}\text { Adults patients undergoing elective } \\
\text { on-pump CABG surgery }(n=25)\end{array}$ & $\begin{array}{l}6 \mathrm{~mL} / \mathrm{kg} \text { with } 5 \mathrm{cmH}_{2} \mathrm{O} \text { of } \\
\text { PEEP }(n=12)\end{array}$ & $\begin{array}{l}12 \mathrm{~mL} / \mathrm{kg} \text { with } 5 \mathrm{cmH}_{2} \mathrm{O} \text { of } \\
\text { PEEP }(n=13)\end{array}$ & Pulmonary mechanics \\
\hline & $\begin{array}{l}\text { Koner et al. } \\
(34)\end{array}$ & $\begin{array}{l}\text { Adult patients undergoing elective } \\
\text { on-pump CABG grafting surgery } \\
(n=44)\end{array}$ & $\begin{array}{l}6 \mathrm{~mL} / \mathrm{kg} \text { with } 5 \mathrm{cmH}_{2} \mathrm{O} \text { of } \\
\text { PEEP }(n=15)\end{array}$ & $\begin{array}{l}10 \mathrm{~mL} / \mathrm{kg} \text { with } 5 \mathrm{cmH}_{2} \mathrm{O} \text { of } \\
\text { PEEP }(n=14) \text { or zero PEEP } \\
(n=15)\end{array}$ & TNF- $\alpha$ and IL-6 levels \\
\hline & $\begin{array}{l}\text { Zupancich } \\
\text { et al. (28) }\end{array}$ & $\begin{array}{l}\text { Adult patients undergoing elective } \\
\text { on-pump CABG surgery }(n=40)\end{array}$ & $\begin{array}{l}8 \mathrm{~mL} / \mathrm{kg} \text { with } 10 \mathrm{cmH}_{2} \mathrm{O} \text { of } \\
\text { PEEP }(n=20)\end{array}$ & $\begin{array}{l}10-12 \mathrm{~mL} / \mathrm{kg} \text { with } \\
2-3 \mathrm{cmH}_{2} \mathrm{O} \text { of PEEP }(n=20)\end{array}$ & $\begin{array}{l}\text { IL-6 and IL-8 in BAL fluid } \\
\text { and plasma }\end{array}$ \\
\hline & $\begin{array}{l}\text { Reis Miranda } \\
\text { et al. (29) }\end{array}$ & $\begin{array}{l}\text { Adult patients undergoing elective } \\
\text { on-pump CABG or valve surgery } \\
(n=62)\end{array}$ & $\begin{array}{l}4-6 \mathrm{~mL} / \mathrm{kg} \text { with } 10 \mathrm{cmH}_{2} \mathrm{O} \text { of } \\
\text { PEEP during }(n=22) \text { or after } \\
(n=18) \text { surgery }\end{array}$ & $\begin{array}{l}6-8 \mathrm{~mL} / \mathrm{kg}(n=22) \text { with } \\
5 \mathrm{cmH}_{2} \mathrm{O} \text { of PEEP }\end{array}$ & $\begin{array}{l}\text { IL-6, IL-8, IL-10, TNF- } \alpha \text {, and } \\
\text { interferon- } \gamma\end{array}$ \\
\hline & $\begin{array}{l}\text { Sundar et al. } \\
(43)\end{array}$ & $\begin{array}{l}\text { Adult patients undergoing elective } \\
\text { cardiac surgery }(n=149)\end{array}$ & $\begin{array}{l}6 \mathrm{~mL} / \mathrm{kg} \text { with PEEP } \\
\text { according to ARDS Network } \\
\text { investigators }(6)(n=75)\end{array}$ & $\begin{array}{l}10 \mathrm{~mL} / \mathrm{kg} \text { with PEEP } \\
\text { according to ARDS Network } \\
\text { investigators }(6)(n=74)\end{array}$ & Time to extubation \\
\hline \multirow[t]{5}{*}{$\begin{array}{l}\text { Abdominal } \\
\text { surgery }\end{array}$} & $\begin{array}{l}\text { Wrigge et al. } \\
\text { (31) }\end{array}$ & $\begin{array}{l}\text { Adult patients undergoing major } \\
\text { abdominal surgery }(n=30)\end{array}$ & $\begin{array}{l}6 \mathrm{~mL} / \mathrm{kg} \text { with } 10 \mathrm{cmH}_{2} \mathrm{O} \text { of } \\
\text { PEEP }(n=15)\end{array}$ & $\begin{array}{l}12 \text { or } 15 \mathrm{~mL} / \mathrm{kg} \text { with zero } \\
\text { PEEP }(n=15)\end{array}$ & $\begin{array}{l}\text { TNF, IL-1, IL-6, IL-8, IL-10, } \\
\text { and IL-12 }\end{array}$ \\
\hline & $\begin{array}{l}\text { Weingarten } \\
\text { et al. (37) }\end{array}$ & $\begin{array}{l}\text { Adult patients aged }>65 \text { years } \\
\text { undergoing major open abdominal } \\
\text { surgery under general anesthesia } \\
(n=40)\end{array}$ & $\begin{array}{l}6 \mathrm{~mL} / \mathrm{kg} \text { with } 12 \mathrm{cmH}_{2} \mathrm{O} \\
\text { of PEEP and recruitment } \\
\text { maneuvers }(n=20)\end{array}$ & $\begin{array}{l}10 \mathrm{~mL} / \mathrm{kg} \text { with no PEEP and } \\
\text { no recruitment maneuvers } \\
(n=20)\end{array}$ & $\begin{array}{l}\text { Oxygenation, pulmonary } \\
\text { mechanics, hemodynamic } \\
\text { stability }\end{array}$ \\
\hline & $\begin{array}{l}\text { Treschan } \\
\text { et al. (40) }\end{array}$ & $\begin{array}{l}\text { Adult patients undergoing elective } \\
\text { upper abdominal surgery lasting } \\
\geq 3 \mathrm{~h} \text { under combined general and } \\
\text { epidural anesthesia }(n=101)\end{array}$ & $\begin{array}{l}6 \mathrm{~mL} / \mathrm{kg} \text { with } 5 \mathrm{cmH}_{2} \mathrm{O} \text { of } \\
\text { PEEP }(n=50)\end{array}$ & $\begin{array}{l}12 \mathrm{~mL} / \mathrm{kg} \text { with } 5 \mathrm{cmH}_{2} \mathrm{O} \text { of } \\
\text { PEEP }(n=51)\end{array}$ & Lung function \\
\hline & $\begin{array}{l}\text { Severgnini } \\
\text { et al. (38) }\end{array}$ & $\begin{array}{l}\text { Adult patients undergoing elective } \\
\text { open abdominal surgery } \geq 2 \mathrm{~h} \\
(n=55)\end{array}$ & $\begin{array}{l}7 \mathrm{~mL} / \mathrm{kg} \text { with } 10 \mathrm{cmH}_{2} \mathrm{O} \\
\text { of PEEP and recruitment } \\
\text { maneuvers }(n=28)\end{array}$ & $\begin{array}{l}9 \mathrm{~mL} / \mathrm{kg} \text { with zero PEEP } \\
(n=27)\end{array}$ & $\begin{array}{l}\text { Modified Clinical Pulmonary } \\
\text { Infection Score, gas } \\
\text { exchange, and pulmonary } \\
\text { functional tests }\end{array}$ \\
\hline & $\begin{array}{l}\text { Futier } \\
\text { et al. (5) }\end{array}$ & $\begin{array}{l}\text { Adults patients at intermediate } \\
\text { to high risk of pulmonary } \\
\text { complications undergoing major } \\
\text { abdominal surgery }(n=400)\end{array}$ & $\begin{array}{l}6-8 \mathrm{~mL} / \mathrm{kg} \text { with } 6-8 \mathrm{cmH}_{2} \mathrm{O} \\
\text { of PEEP and recruitment } \\
\text { maneuvers }(n=200)\end{array}$ & $\begin{array}{l}10-12 \mathrm{~mL} / \mathrm{kg} \text { with no } \\
\text { PEEP and no recruitment } \\
\text { maneuvers }(n=200)\end{array}$ & $\begin{array}{l}\text { A composite of } \\
\text { major pulmonary } \\
\text { and extrapulmonary } \\
\text { complications occurring by } \\
\text { day } 7 \text { after surgery }\end{array}$ \\
\hline \multirow[t]{5}{*}{ Others } & Cai et al. (39) & $\begin{array}{l}\text { Adults patients aged } 20-50 \text { years } \\
\text { with body mass index undergoing } \\
\text { elective excision of intracranial } \\
\text { lesions }(n=16)\end{array}$ & $6 \mathrm{~mL} / \mathrm{kg}$ without PEEP $(n=8)$ & $\begin{array}{l}10 \mathrm{~mL} / \mathrm{kg} \text { without PEEP } \\
(n=8)\end{array}$ & Atelectasis (by CT and ABG) \\
\hline & $\begin{array}{l}\text { Memtsoudis } \\
\text { et al. (32) }\end{array}$ & $\begin{array}{l}\text { Adult patients undergoing elective } \\
\text { lumbar decompression and fusion } \\
\text { in prone position under general } \\
\text { anesthesia }(n=26)\end{array}$ & $\begin{array}{l}6 \mathrm{~mL} / \mathrm{kg} \text { with } 8 \mathrm{cmH}_{2} \mathrm{O} \text { of } \\
\text { PEEP }(n=13)\end{array}$ & $\begin{array}{l}12 \mathrm{~mL} / \mathrm{kg} \text { with zero PEEP } \\
(n=13)\end{array}$ & $\begin{array}{l}\text { Plasma levels of IL- } 6 \text { and } \\
\| \mathrm{L}-8 \text {, and urinary levels of } \\
\text { desmosine }\end{array}$ \\
\hline & $\begin{array}{l}\text { Choi et al. } \\
\text { (33) }\end{array}$ & $\begin{array}{l}\text { Adult patients undergoing a surgical } \\
\text { procedure } \geq 5 \mathrm{~h}(n=40)\end{array}$ & $\begin{array}{l}6 \mathrm{~mL} / \mathrm{kg} \text { with } 10 \mathrm{cmH}_{2} \mathrm{O} \text { of } \\
\text { PEEP }(n=21)\end{array}$ & $\begin{array}{l}12 \mathrm{~mL} / \mathrm{kg} \text { without PEEP } \\
(n=19)\end{array}$ & $\begin{array}{l}\text { Markers of coagulation and } \\
\text { fibrinolysis }\end{array}$ \\
\hline & $\begin{array}{l}\text { Wolthuis } \\
\text { et al. (30) }\end{array}$ & $\begin{array}{l}\text { Adult patients undergoing a surgical } \\
\text { procedure } \geq 5 \mathrm{~h}(n=40)\end{array}$ & $\begin{array}{l}6 \mathrm{~mL} / \mathrm{kg} \text { with } 10 \mathrm{cmH}_{2} \mathrm{O} \text { of } \\
\text { PEEP }(n=21)\end{array}$ & $\begin{array}{l}12 \mathrm{~mL} / \mathrm{kg} \text { without PEEP } \\
(n=19)\end{array}$ & $\begin{array}{l}\text { Polymorphonuclear cell } \\
\text { influx, changes in levels of } \\
\text { inflammatory markers, and } \\
\text { nucleosomes in BAL fluid } \\
\text { and/or blood }\end{array}$ \\
\hline & $\begin{array}{l}\text { Determann } \\
\text { et al. (35) }\end{array}$ & $\begin{array}{l}\text { Adult patients undergoing a surgical } \\
\text { procedure } \geq 5 \mathrm{~h}(n=40)\end{array}$ & $\begin{array}{l}6 \mathrm{~mL} / \mathrm{kg} \text { with } 10 \mathrm{cmH}_{2} \mathrm{O} \text { of } \\
\text { PEEP }(n=21)\end{array}$ & $\begin{array}{l}12 \mathrm{~mL} / \mathrm{kg} \text { without PEEP } \\
(n=19)\end{array}$ & $\begin{array}{l}\text { Local and systemic levels of } \\
\text { Clara cell protein }\end{array}$ \\
\hline
\end{tabular}

$V_{T}$, tidal volumes; $C A B G$, coronary artery bypass grafting; PEEP, positive end-expiratory pressure; TNF, tumor necrosis factor; IL, interleukin; BAL, bronchoalveolar lavage; CPB, cardiopulmonary bypass; ARDS, acute respiratory distress syndrome; CT, computed tomography; ABG, arterial blood gas.

a similarly mixed profile in response to lung protective MV (29). High $\mathrm{V}_{\mathrm{T}}$ /zero end-expiratory pressure (ZEEP) MV does appear to lead to procoagulant activation in the alveolar space (33). Many other inflammatory markers, including tumor necrosis factor-alpha (TNF- $\alpha$ ), interferon (IFN)- $\gamma$, IL-1, IL- $1 \alpha$, IL- $1 \beta$, IL-6, IL-12, macrophage inflammatory protein $1 \alpha$, and macrophage inflammatory protein $1 \beta$, or other markers of lung epithelial injury have not been demonstrated to change in response to lung protective ventilation (29-31, 34, 35).

Other studies have demonstrated improved perioperative pulmonary mechanics as a surrogate outcome. One single-center RCT included 25 patients undergoing elective CABG showed a 
greater reduction in both dynamic and static lung compliance in patients receiving conventional $\mathrm{MV}$, suggesting lung protective MV resulted in improved pulmonary mechanics (36). RCTs in abdominal surgery had varied results showing improved (37), unchanged $(38,39)$, and degraded (40) pulmonary mechanics in patients receiving lung protective $\mathrm{MV}$. An improvement in the partial pressure of arterial oxygen $\left(\mathrm{PaO}_{2}\right) /$ Fraction of inspired oxygen $\left(\mathrm{FiO}_{2}\right)$ ratio in abdominal surgery patients appears to reflect the use of recruitment maneuvers more than any particular lung protective strategy $(37,40)$.

\section{Lung Protective Ventilation and Clinical Outcomes}

Several retrospective studies have investigated the association between MV strategies in the operating room and clinical outcomes. A retrospective evaluation of patients admitted to the ICU with postoperative hypoxemic respiratory failure, requiring $\mathrm{MV}$, showed that a high $\mathrm{V}_{\mathrm{T}}$ to ideal body weight (IBW) ratio was an independent risk factor for the development of ARDS (41). While a retrospective study of billing data for over 69,000 patients undergoing non-cardiac surgery did not show any effect of $\mathrm{V}_{\mathrm{T}}$ on postoperative respiratory complications (24). Another retrospective study of more than 29,000 patients reported that $\mathrm{V}_{\mathrm{T}}$ of $6-8 \mathrm{~mL} / \mathrm{kg}$ IBW were associated with a significant increase in 30-day mortality compared with $\mathrm{V}_{\mathrm{T}}$ of $8-10 \mathrm{~mL} / \mathrm{kg}$ IBW (hazard ratio $1.6, p=0.0002)$ (42). The authors hypothesized that the increased mortality may be related to the combination of lower $\mathrm{V}_{\mathrm{T}}$ and low PEEP $\left(\leq 5 \mathrm{cmH}_{2} \mathrm{O}\right)(42)$.

Prospective RCTs of MV in the operating room have specifically targeted high-risk surgical groups, primarily cardiac and abdominal surgery patients. One single-center RCT investigated duration of intubation for cardiac surgery patients by comparing ventilation with low vs. high $\mathrm{V}_{\mathrm{T}}$ ventilation. A higher proportion of patients were extubated $6 \mathrm{~h}$ postoperatively in the low $\mathrm{V}_{\mathrm{T}}$ group ( 37.3 vs. $20.3 \% ; p=0.02$ ) and fewer patients in the low $\mathrm{V}_{\mathrm{T}}$ group required re-intubation (0.3 vs. 9.5\%; $p=0.03$ ) (43). In two RCTs of patients undergoing open abdominal surgery, lower $V_{T}$ ventilation combined with PEEP and recruitment maneuvers decreased respiratory complications as measured by two different postoperative pulmonary complication scores when compared to higher $\mathrm{V}_{\mathrm{T}}$ ventilation with ZEEP and no recruitment maneuvers $(5,38)$. The IMPROVE trial also found that patients receiving lung protective ventilation and recruitment maneuvers had decreased postoperative non-invasive ventilation and intubation requirements (5.0 vs. $17.0 \%, p=0.001$ ), and shorter length of hospital stay (mean difference, -2.45 days, $p=0.006$ ) (5). However, in 101 patients undergoing upper abdominal surgery who were randomized to low $\mathrm{V}_{\mathrm{T}}$ ventilation (6 mL/kg PBW) with $5 \mathrm{cmH}_{2} \mathrm{O}$ PEEP or to higher $\mathrm{V}_{\mathrm{T}}$ ventilation (12 mL/kg PBW) also with $5 \mathrm{cmH}_{2} \mathrm{O}$ PEEP, there was no significant difference in postoperative pulmonary complications (40). In the largest prospective multicenter RCT, conducted by the Protective Ventilation (PROVE) Network Investigators, 900 patients were allocated either to a high level of PEEP $\left(12 \mathrm{cmH}_{2} \mathrm{O}\right)$ with recruitment maneuvers (higher PEEP group) or a low level of PEEP $\left(\leq 2 \mathrm{cmH}_{2} \mathrm{O}\right.$ ) without recruitment maneuvers (lower PEEP group) while receiving $8 \mathrm{~mL} / \mathrm{kg} \mathrm{V}_{\mathrm{T}}$ (PROVHILO trial). In this study, postoperative pulmonary and extrapulmonary complications were not significantly different between the two groups although hypotension happened more frequently in the higher PEEP group (relative risk 1.29; $p=0.0016$ ) and those in the higher PEEP group had a greater need for vasopressors than those in the lower PEEP group (relative risk 1.20; $p=0.0016$ ) (44). The results of these trials suggest an important interaction between $\mathrm{V}_{\mathrm{T}}$ and PEEP affecting clinical outcomes.

\section{Lung Protective Ventilation Meta-Analyses}

The recently updated Cochrane meta-analysis evaluated 12 studies with 1012 participants comparing specifically low vs. high $\mathrm{V}_{\mathrm{T}}$ ventilation in the operating room (45). They found no difference in 30 -day mortality (risk ratio (RR) $0.79,95 \%$ confidence interval (CI) $0.40-1.54$ ), but the low $\mathrm{V}_{\mathrm{T}}$ cohort did show a decrease in postoperative pneumonia and a decreased requirement for both invasive and non-invasive postoperative ventilation (45). Decreased rates of pulmonary infection have been confirmed by other meta-analyses of lung protective ventilation (including interventions in addition to low $\mathrm{V}_{\mathrm{T}}$ ) (46-48). These additional meta-analyses also failed to demonstrate a mortality benefit to intraoperative lung protective ventilation $(46,47)$.

\section{Lung Protective Ventilation in Anesthetic Practice}

While the data to support lung protective ventilation in the operating room remains unclear, it is worthwhile to examine the current state of anesthetic practice regarding MV. One crosssectional analysis of intraoperative ventilation during elective abdominal surgery in the United States showed that ventilator settings were non-uniform and ventilation with $\mathrm{V}_{\mathrm{T}}>10 \mathrm{~mL} / \mathrm{kg}$ PBW is still common (17.5\%). BMI $\geq 30$, female gender, and height $<165 \mathrm{~cm}$ may predispose certain patients to receive large $\mathrm{V}_{\mathrm{T}}$ during general anesthesia as providers likely overestimate PBW in this patient group (49). Despite the high prevalence of high $\mathrm{V}_{\mathrm{T}}$ ventilation in the operating room, a targeted study of the management of hypoxemic patients (defined by $\mathrm{P} / \mathrm{F}$ ratio) in the operating room found $\mathrm{V}_{\mathrm{T}}$, and peak inspiratory pressure (PIP) have been decreasing annually while PEEP has been increasing (50). Unfortunately, worsened hypoxemia (lower $\mathrm{P} / \mathrm{F}$ ratio) correlated most closely with higher $\mathrm{FiO}_{2}$ and PIP, suggesting that patients who would most benefit from lung protective ventilation are not receiving it (50). Investigators in Australia performed an audit in 272 patients undergoing general anesthesia for three consecutive days in 2013. They showed that a median $\mathrm{V}_{\mathrm{T}}$ was $9.5 \mathrm{~mL} / \mathrm{kg} \mathrm{PBW}$, suggesting that the practice of $\mathrm{MV}$ in the operating room does not always reflect recent studies (51). There are several ongoing studies investigating variation of MV setting within/between centers (52) ${ }^{1}$.

\section{DISCUSSION}

The translation of research from the ICU to the operating room can be difficult for several reasons. Patients receiving MV in the

${ }^{1}$ IVENT. International Survery on VENTilation Practice (iVENT). In: PROVEnet [Internet]. Available from: https://sites.google.com/site/iventsurvey/. 
operating room during general anesthesia commonly lack the derangements in gas exchange and pulmonary mechanics seen in the ICU. While general anesthesia does induce atelectasis, the atelectasis is well-tolerated and relatively short-lived (1-3). Rates of respiratory complications remain low in most populations and the short duration of MV likely affects lung compliance less than a prolonged course of ventilation in ICU. Furthermore, ICU patients are more likely to have comorbid illnesses, such as cardiovascular instability and shock, acid-base abnormalities, and pro-inflammatory states, such as sepsis, which affect the goals of MV.

Based on published ICU data, studies of lung protective ventilation in the operating room generally have used 6-8 mL/ kg PBW as low $V_{T}$ ventilation (Table 1), which may not be the ideal $V_{T}$ for surgical patients (42). Furthermore, studies in the perioperative setting have used low $\mathrm{V}_{\mathrm{T}}$ combined with PEEP and/or recruitment maneuvers as the lung protective strategies. Although low $\mathrm{V}_{\mathrm{T}}$ ventilation is clearly an important factor of the lung protective ventilation (53), it is still unclear how we should combine these "lung protective strategies," including PEEP and recruitment maneuvers, into a unified best practice for MV in the operating room (44). A subsequent ongoing international multicenter RCT, aims to compare a ventilation strategy using higher levels of PEEP with recruitment maneuvers to one using lower levels of PEEP without recruitment maneuvers in obese patients at risk of postoperative pulmonary complications ${ }^{2}$. This study design hints at the holy grail for intraoperative ventilation: targeted interventions for specific patients. While still heterogeneous themselves, patients with acute respiratory failure and ARDS

${ }^{2}$ Technische Universität Dresden. Protective Ventilation with Higher Versus Lower PEEP during General Anesthesia for Surgery in Obese Patients (PROBESE). In: ClinicalTrials.gov [Internet]. Available from: http://clinicaltrials.gov/show/ NCT02148692.

\section{REFERENCES}

1. Duggan M, Kavanagh BP. Pulmonary atelectasis: a pathogenic perioperative entity. Anesthesiology (2005) 102(4):838-54. doi:10.1097/00000542200504000-00021

2. Gunnarsson L, Tokics L, Gustavsson H, Hedenstierna G. Influence of age on atelectasis formation and gas exchange impairment during general anaesthesia. Br J Anaesth (1991) 66(4):423-32. doi:10.1093/bja/66.4.423

3. Edmark L, Kostova-Aherdan K, Enlund M, Hedenstierna G. Optimal oxygen concentration during induction of general anesthesia. Anesthesiology (2003) 98(1):28-33. doi:10.1097/00000542-200301000-00008

4. Bendixen $\mathrm{HH}$, Hedley-Whyte J, Laver MB. Impaired oxygenation in surgical patients during general anesthesia with controlled ventilation. A concept of atelectasis. N Engl JMed (1963) 269:991-6. doi:10.1056/ NEJM196311072691901

5. Futier E, Constantin JM, Paugam-Burtz C, Pascal J, Eurin M, Neuschwander A, et al. A trial of intraoperative low-tidal-volume ventilation in abdominal surgery. N Engl J Med (2013) 369(5):428-37. doi:10.1056/NEJMoa1301082

6. The Acute Respiratory Distress Syndrome Network. Ventilation with lower tidal volumes as compared with traditional tidal volumes for acute lung injury and the acute respiratory distress syndrome. N Engl J Med (2000) 342(18):1301-8. doi:10.1056/NEJM200005043421801

7. Kuchnicka K, Maciejewski D. Ventilator-associated lung injury. Anaesthesiol Intensive Ther (2013) 45(3):164-70. doi:10.5603/AIT.2013.0034 in the ICU are substantially more homogeneous than the morass of patients undergoing general anesthesia in the operating room. This heterogeneity may, in part, explain the disparate findings in previous studies. However, as we gain a better understanding of the risks and benefits of the various aspects of lung protective strategies, we can more effectively target-specific patient populations for intervention.

\section{CONCLUSION}

As lung protective strategies, including low $\mathrm{V}_{\mathrm{T}}$ ventilation, higher PEEP, and/or recruitment maneuvers, continue to evolve, they may also provide benefit to patients undergoing general anesthesia. Larger trials of specific ventilator strategies across different populations are required to evaluate different lung protective strategies and their interaction with different groups of surgical patients to clarify the benefit or harm of lung protective ventilation in the operating room. Furthermore, we need investigations into current practice strategies of clinical anesthesiologists, in order to help shape how new data are applied in the operating room.

\section{AUTHOR CONTRIBUTIONS}

SK made contributions to conception and design, participated in drafting the article, and revised it critically for important intellectual content. NS participated in drafting the article and revised it critically for important intellectual content. BB participated in drafting the article and revised it critically for important intellectual content. MS participated in drafting the article and revised it critically for important intellectual content. $\mathrm{AB}$ participated in drafting the article and revised it critically for important intellectual content. DS made contributions to conception and design, participated in drafting the article, and revised it critically for important intellectual content.

8. Oeckler RA, Hubmayr RD. Ventilator-associated lung injury: a search for better therapeutic targets. Eur Respir J (2007) 30(6):1216-26. doi:10.1183/ 09031936.00104907

9. Gattinoni L, Protti A, Caironi P, Carlesso E. Ventilator-induced lung injury: the anatomical and physiological framework. Crit Care Med (2010) 38(10 Suppl):S539-48. doi:10.1097/CCM.0b013e3181f1fcf7

10. Tremblay L, Valenza F, Ribeiro SP, Li J, Slutsky AS. Injurious ventilatory strategies increase cytokines and c-fos m-RNA expression in an isolated rat lung model. J Clin Invest (1997) 99(5):944-52. doi:10.1172/JCI119259

11. von Bethmann AN, Brasch F, Nusing R, Vogt K, Volk HD, Muller KM, et al. Hyperventilation induces release of cytokines from perfused mouse lung. Am J Respir Crit Care Med (1998) 157(1):263-72. doi:10.1164/ ajrccm.157.1.9608052

12. Imanaka $H$, Shimaoka $M$, Matsuura $N$, Nishimura $M$, Ohta $N$, Kiyono $H$. Ventilator-induced lung injury is associated with neutrophil infiltration, macrophage activation, and TGF-beta 1 mRNA upregulation in rat lungs. Anesth Analg (2001) 92(2):428-36. doi:10.1097/00000539-200102000-00029

13. Tsuno K, Miura K, Takeya M, Kolobow T, Morioka T. Histopathologic pulmonary changes from mechanical ventilation at high peak airway pressures. Am Rev Respir Dis (1991) 143(5 Pt 1):1115-20. doi:10.1164/ ajrccm/143.5_Pt_1.1115

14. Whitehead T, Slutsky AS. The pulmonary physician in critical care ${ }^{*} 7$ : ventilator induced lung injury. Thorax (2002) 57(7):635-42. doi:10.1136/ thorax.57.7.635 
15. Uhlig S. Ventilation-induced lung injury and mechanotransduction: stretching it too far? Am J Physiol Lung Cell Mol Physiol (2002) 282(5):L892-6. doi:10.1152/ajplung.00124.2001

16. Greenfield LJ, Ebert PA, Benson DW. Atelectasis and surface tension properties of lung extracts following positive pressure ventilation and overinflation. Surg Forum (1963) 14:239-40.

17. Greenfield LJ, Ebert PA, Benson DW. Effect of positive pressure ventilation on surface tension properties of lung extracts. Anesthesiology (1964) 25:312-6. doi:10.1097/00000542-196405000-00009

18. Hickling KG, Henderson SJ, Jackson R. Low mortality associated with low volume pressure limited ventilation with permissive hypercapnia in severe adult respiratory distress syndrome. Intensive Care Med (1990) 16(6):372-7. doi:10.1007/BF01735174

19. Zambon M, Vincent JL. Mortality rates for patients with acute lung injury/ ARDS have decreased over time. Chest (2008) 133(5):1120-7. doi:10.1378/ chest.07-2134

20. Amato MB, Barbas CS, Medeiros DM, Magaldi RB, Schettino GP, LorenziFilho G, et al. Effect of a protective-ventilation strategy on mortality in the acute respiratory distress syndrome. N Engl J Med (1998) 338(6):347-54. doi:10.1056/NEJM199802053380602

21. Needham DM, Yang T, Dinglas VD, Mendez-Tellez PA, Shanholtz C, Sevransky JE, et al. Timing of low tidal volume ventilation and intensive care unit mortality in acute respiratory distress syndrome. A prospective cohort study. Am J Respir Crit Care Med (2015) 191(2):177-85. doi:10.1164/ rccm.201409-1598OC

22. Gajic O, Dara SI, Mendez JL, Adesanya AO, Festic E, Caples SM, et al. Ventilator-associated lung injury in patients without acute lung injury at the onset of mechanical ventilation. Crit Care Med (2004) 32(9):1817-24. doi:10.1097/01.CCM.0000133019.52531.30

23. Gajic O, Frutos-Vivar F, Esteban A, Hubmayr RD, Anzueto A. Ventilator settings as a risk factor for acute respiratory distress syndrome in mechanically ventilated patients. Intensive Care Med (2005) 31(7):922-6. doi:10.1007/ s00134-005-2625-1

24. Ladha K, Vidal Melo MF, McLean DJ, Wanderer JP, Grabitz SD, Kurth T, et al. Intraoperative protective mechanical ventilation and risk of postoperative respiratory complications: hospital based registry study. BMJ (2015) 351:h3646. doi:10.1136/bmj.h3646

25. Kallet RH, Siobal MS, Alonso JA, Warnecke EL, Katz JA, Marks JD. Lung collapse during low tidal volume ventilation in acute respiratory distress syndrome. Respir Care (2001) 46(1):49-52.

26. Viitanen A, Salmenpera M, Heinonen J. Right ventricular response to hypercarbia after cardiac surgery. Anesthesiology (1990) 73(3):393-400. doi:10.1097/00000542-199009000-00005

27. Wrigge H, Uhlig U, Baumgarten G, Menzenbach J, Zinserling J, Ernst M, et al. Mechanical ventilation strategies and inflammatory responses to cardiac surgery: a prospective randomized clinical trial. Intensive Care Med (2005) 31(10):1379-87. doi:10.1007/s00134-005-2767-1

28. Zupancich E, Paparella D, Turani F, Munch C, Rossi A, Massaccesi S, et al. Mechanical ventilation affects inflammatory mediators in patients undergoing cardiopulmonary bypass for cardiac surgery: a randomized clinical trial. J Thorac Cardiovasc Surg (2005) 130(2):378-83. doi:10.1016/j. jtcvs.2004.11.061

29. Reis Miranda D, Gommers D, Struijs A, Dekker R, Mekel J, Feelders R, et al. Ventilation according to the open lung concept attenuates pulmonary inflammatory response in cardiac surgery. Eur J Cardiothorac Surg (2005) 28(6):889-95. doi:10.1016/j.ejcts.2005.10.007

30. Wolthuis EK, Choi G, Dessing MC, Bresser P, Lutter R, Dzoljic M, et al. Mechanical ventilation with lower tidal volumes and positive end-expiratory pressure prevents pulmonary inflammation in patients without preexisting lung injury. Anesthesiology (2008) 108(1):46-54. doi:10.1097/01. anes.0000296068.80921.10

31. Wrigge H, Uhlig U, Zinserling J, Behrends-Callsen E, Ottersbach G, Fischer $\mathrm{M}$, et al. The effects of different ventilatory settings on pulmonary and systemic inflammatory responses during major surgery. Anesth Analg (2004) 98(3):775-81, table of contents. doi:10.1213/01. ANE.0000100663.11852.BF

32. Memtsoudis SG, Bombardieri AM, Ma Y, Girardi FP. The effect of low versus high tidal volume ventilation on inflammatory markers in healthy individuals undergoing posterior spine fusion in the prone position: a randomized controlled trial. J Clin Anesth (2012) 24(4):263-9. doi:10.1016/j. jclinane.2011.08.003

33. Choi G, Wolthuis EK, Bresser P, Levi M, van der Poll T, Dzoljic $\mathrm{M}$, et al. Mechanical ventilation with lower tidal volumes and positive end-expiratory pressure prevents alveolar coagulation in patients without lung injury. Anesthesiology (2006) 105(4):689-95. doi:10.1097/00000542-200610000-00013

34. Koner O, Celebi S, Balci H, Cetin G, Karaoglu K, Cakar N. Effects of protective and conventional mechanical ventilation on pulmonary function and systemic cytokine release after cardiopulmonary bypass. Intensive Care Med (2004) 30(4):620-6. doi:10.1007/s00134-003-2104-5

35. Determann RM, Wolthuis EK, Choi G, Bresser P, Bernard A, Lutter R, et al. Lung epithelial injury markers are not influenced by use of lower tidal volumes during elective surgery in patients without preexisting lung injury. Am J Physiol Lung Cell Mol Physiol (2008) 294(2):L344-50. doi:10.1152/ ajplung.00268.2007

36. Chaney MA, Nikolov MP, Blakeman BP, Bakhos M. Protective ventilation attenuates postoperative pulmonary dysfunction in patients undergoing cardiopulmonary bypass. J Cardiothorac Vasc Anesth (2000) 14(5):514-8. doi:10.1053/jcan.2000.9487

37. Weingarten TN, Whalen FX, Warner DO, Gajic O, Schears GJ, Snyder MR, et al. Comparison of two ventilatory strategies in elderly patients undergoing major abdominal surgery. Br J Anaesth (2010) 104(1):16-22. doi:10.1093/bja/ aep319

38. Severgnini P, Selmo G, Lanza C, Chiesa A, Frigerio A, Bacuzzi A, et al. Protective mechanical ventilation during general anesthesia for open abdominal surgery improves postoperative pulmonary function. Anesthesiology (2013) 118(6):1307-21. doi:10.1097/ALN.0b013e31829102de

39. Cai H, Gong H, Zhang L, Wang Y, Tian Y. Effect of low tidal volume ventilation on atelectasis in patients during general anesthesia: a computed tomographic scan. J Clin Anesth (2007) 19(2):125-9. doi:10.1016/j.jclinane.2006.08.008

40. Treschan TA, Kaisers W, Schaefer MS, Bastin B, Schmalz U, Wania V, et al. Ventilation with low tidal volumes during upper abdominal surgery does not improve postoperative lung function. Br J Anaesth (2012) 109(2):263-71. doi:10.1093/bja/aes140

41. Hughes CG, Weavind L, Banerjee A, Mercaldo ND, Schildcrout JS, Pandharipande PP. Intraoperative risk factors for acute respiratory distress syndrome in critically ill patients. Anesth Analg (2010) 111(2):464-7. doi:10.1213/ANE.0b013e3181d8a16a

42. Levin MA, McCormick PJ, Lin HM, Hosseinian L, Fischer GW. Low intraoperative tidal volume ventilation with minimal PEEP is associated with increased mortality. Br J Anaesth (2014) 113(1):97-108. doi:10.1093/bja/aeu054

43. Sundar S, Novack V, Jervis K, Bender SP, Lerner A, Panzica P, et al. Influence of low tidal volume ventilation on time to extubation in cardiac surgical patients. Anesthesiology (2011) 114(5):1102-10. doi:10.1097/ALN.0b013e318215e254

44. PROVE Network Investigators for the Clinical Trial Network of the European Society of Anaesthesiology, Hemmes SN, Gama de Abreu M, Pelosi P, Schultz MJ. High versus low positive end-expiratory pressure during general anaesthesia for open abdominal surgery (PROVHILO trial): a multicentre randomised controlled trial. Lancet (2014) 384(9942):495-503. doi:10.1016/ S0140-6736(14)60416-5

45. Guay J, Ochroch EA. Intraoperative use of low volume ventilation to decrease postoperative mortality, mechanical ventilation, lengths of stay and lung injury in patients without acute lung injury. Cochrane Database Syst Rev (2015) 12:CD011151. doi:10.1002/14651858.CD011151.pub2

46. Gu WJ, Wang F, Liu JC. Effect of lung protective ventilation with lower tidal volumes on clinical outcomes among patients undergoing surgery: a meta-analysis of randomized controlled trials. CMAJ (2015) 187(3):E101-9. doi:10.1503/cmaj.141005

47. Tao T, Bo L, Chen F, Xie Q, Zou Y, Hu B, et al. Effect of protective ventilation on postoperative pulmonary complications in patients undergoing general anaesthesia: a meta-analysis of randomised controlled trials. BMJ Open (2014) 4(6):e005208. doi:10.1136/bmjopen-2014-005208

48. Hemmes SN, Serpa Neto A, Schultz MJ. Intraoperative ventilatory strategies to prevent postoperative pulmonary complications: a meta-analysis. Curr Opin Anaesthesiol (2013) 26(2):126-33. doi:10.1097/ACO.0b013e32835e1242

49. Fernandez-Bustamante A, Wood CL, Tran ZV, Moine P. Intraoperative ventilation: incidence and risk factors for receiving large tidal volumes during general anesthesia. BMC Anesthesiol (2011) 11:22. doi:10.1186/1471-2253-11-22 
50. Blum JM, Fetterman DM, Park PK, Morris M, Rosenberg AL. A description of intraoperative ventilator management and ventilation strategies in hypoxic patients. Anesth Analg (2010) 110(6):1616-22. doi:10.1213/ ANE.0b013e3181da82e1

51. Karalapillai D, Weinberg L, Galtieri J, Glassford N, Eastwood G, Darvall J, et al. Current ventilation practice during general anaesthesia: a prospective audit in Melbourne, Australia. BMC Anesthesiol (2014) 14:85. doi:10.1186/1471-2253-14-85

52. Hemmes SN, de Abreu MG, Pelosi P, Schultz MJ. ESA clinical trials network 2012: LAS VEGAS - local assessment of ventilatory management during general anaesthesia for surgery and its effects on postoperative pulmonary complications: a prospective, observational, international, multicentre cohort study. Eur J Anaesthesiol (2013) 30(5):205-7. doi:10.1097/ EJA.0b013e32835fcab3

53. Guldner A, Kiss T, Serpa Neto A, Hemmes SN, Canet J, Spieth PM, et al. Intraoperative protective mechanical ventilation for prevention of postoperative pulmonary complications: a comprehensive review of the role of tidal volume, positive end-expiratory pressure, and lung recruitment maneuvers. Anesthesiology (2015) 123(3):692-713. doi:10.1097/ ALN.0000000000000754

Conflict of Interest Statement: The authors declare that the research was conducted in the absence of any commercial or financial relationships that could be construed as a potential conflict of interest.

Copyright () 2016 Kimura, Stoicea, Rosero Britton, Shabsigh, Branstiter and Stahl. This is an open-access article distributed under the terms of the Creative Commons Attribution License (CC BY). The use, distribution or reproduction in other forums is permitted, provided the original author(s) or licensor are credited and that the original publication in this journal is cited, in accordance with accepted academic practice. No use, distribution or reproduction is permitted which does not comply with these terms. 